\title{
Sinergi Dan Optimalisasi Green Banking Perbankan Syariah Dalam Mewujudkan Suistainable Finance
}

\author{
Rahmayati Nasution \\ Fakultas Agama Islam Universitas Muhammadiyah Sumatera Utara \\ Jl. Kapten Muchtar Basri No. 3 Medan 20221 \\ e-mail: Rahmayati143@yahoo.co.id
}

\begin{abstract}
ABSTRAK
Penelitian ini bertujuan untuk mengetahui bagaimana tanggung jawab perbankan syariah dalam pelaksanaan Green Banking dalam kebijakan penyaluran pembiayaan kepada nasabah, dan sinergi serta optimalisasi dalam mewujudkan suistainable finance. Jenis penelitian ini menggunakan Pendekatan Berpikir Sistem. Data penelitian adalah data sekunder yang diperoleh dari data literatur yang mendukung dan diperoleh dari website ojk. Teknik Pemodelan dilakukan guna menghasilkan suatu formulasi struktur model yang menyerupai sifatsifat dan perilaku sistem dunia nyata yang kompleks. Hasil penelitian bahwa green banking adalah upaya untuk merubah paradigma dalam pembangunan bank syariah dapat bertanggung jawab melalui cara pembiayaannya untuk turut berperan dalam mencegah perusakan lingkungan.
\end{abstract}

Kata Kunci: Sinergi, Optimalisasi, Green Banking, Suistainable Finance. 
Published July 2018

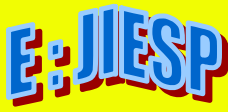

EKONOMIKAWAN : Jurnal Ilmu Ekonomi dan Studi Pembangunan

ISSN : 1693-7600 (Print), ISSN : 2598-0157 (Online), http://jurnal.umsu.ac.Id/index.php/ekawan

\title{
Synergy And Optimization Of Sharia Banking Green Banking In Realizing Suistainable Finance
}

\begin{abstract}
This study aims to find out how the responsibility of sharia banking in the implementation of Green Banking in the policy of financing distribution to customers, and synergy and optimization in realizing suistainable finance. This type of research uses the System Thinking Approach. Research data is secondary data obtained from literature data that support and obtained from website ojk.Teknik Modeling done to produce a model structure formulation that resembles the nature and behavior of complex real world system. The result of the research that green banking is an effort to change the paradigm in sharia bank development can be responsible through the way of financing to play a role in preventing environmental destruction.
\end{abstract}

\section{Keywords: Synergy, Optimization, Green Banking, Suistainable Finance.}

\section{PENDAHULUAN}

Kementerian Lingkungan Hidup Republik Indonesia lebih dari 30 tahun, Indonesia telah menempatkan pertumbuhan ekonomi sebagai indikator keberhasilan. Dengan paradigma pembangunan yang dianut, pertumbuhan ekonomi sebelum terjadi krisis ekonomi, melaju dengan tingkat pertumbuhan hampir mencapai $8 \%$ per-tahun. Namun demikian, pertimbangannya adalah bahwa laju pertumbuhan ekonomi tersebut harus ditebus dengan kerusakan sumber daya alam dan lingkungan yang hebat. Kerusakan lingkungan (atau faktor yang mempunyai potensi menimbulkan kerusakan lingkungan) tidak menurun bahkan cenderung meningkat. Hal ini terlihat pada beberapa sektor strategis di dalam pembangunan Indonesia seperti sektor kehutanan, pertanian dan perikanan maupun pertambangan. Hal ini sebagai akibat pengelolaan sumber daya alam dan lingkungan yang cenderung mengarah pada pola pengelolaan yang berorientasi jangka pendek (berdasarkan www.menlh.go.id).

Perbankan perlu beradaptasi secara interdepedensial dengan lingkungan, dalam hal ini dikenal dengan istilah green banking, sebagai cara untuk memenangkan persaingan pasar sekaligus turut melestarikan lingkungan, karena perbankan tidak bisa hidup tanpa lingkungan yang memadai. Peran serta sektor perbankan dalam rangka mendukung pengelolaan lingkungan hidup (green banking) sejalan dengan undang-undang dan diamanatkan dalam Pasal 8 Undang-undang No. 7 Tahun 1992 tentang Perbankan sebagaimana telah diubah dengan Undang-undang No. 10 Tahun 1998, yang berbunyi bahwa: (1) Dalam memberikan kredit atau pembiayaan berdasarkan syariah, Bank Umum wajib mempunyai keyakinan berdasarkan analisa yang mendalam atas itikad dan kemampuan serta kesanggupan nasabah debitur untuk melunasi utangnya atau mengembalikan pembiayaan dimaksud sesuai dengan yang diperjanjikan. 
Published July 2018

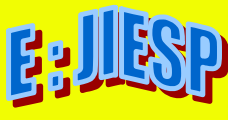

EKONOMIKAWAN : Jurnal Ilmu Ekonomi dan Studi Pembangunan

ISSN : 1693-7600 (Print), ISSN : 2598-0157 (Online), http://jurnal.umsu.ac.Id/index.php/ekawan

Dengan demikian keyakinan berdasarkan analisa yang mendalam dalam memberikan kredit atau pembiayaan berdasarkan Prinsip Syariah yang sehat, bank harus pula memperhatikan hasil Analisis Mengenai Dampak Lingkungan (AMDAL) bagi perusahaan yang berskala besar dan atau beresiko tinggi agar proyek yang dibiayai tetap menjaga kelestarian lingkungan.

Pada masa lalu pihak yang harus bertanggung jawab terhadap dampak lingkungan yang ditimbulkan ialah pelaku usaha (industri), sementara bank sebagai pihak yang memberikan pembiayaan terbebas dari tanggung jawab tersebut. Namun dengan adanya wacana green economy, bank diharapkan dapat bertanggung jawab melalui cara pembiayaannya, diharuskan untuk turut berperan dalam perusakan lingkungan. Artinya, bank syariah harus mempertimbangkan bahwa kegiatan yang dijalankan oleh debiturnya memiliki dampak negatif terhadap lingkungan atau tidak. Terlebih lagi bank syariah dimana prinsip dasarnya untuk melakukan filterisasi atau peraturan pemilihan pemberian pembiayaan yang ketat. Diharapkan, bank syariah dapat menyambut baik dan menjadi acuan dalam penerapan regulasi tersebut.

Besarnya pengaruh secara tidak langsung lembaga keuangan khususnya bank dalam pembiayaan kegiatan produksi terhadap kelestarian lingkungan hidup, oleh karenanya pemerintah terus memberikan perhatian pada masalah ini, dan bahkan kerjasama antara BI dan KLH terus dilanjutkan. Kesepakatan Bersama Kementerian Lingkungan Hidup (KLH) dan Otoritas Keuangan (OJK). Jakarta, 26 Mei 2014. Kementerian Lingkungan Hidup (KLH) dan Otoritas Jasa Keuangan (OJK) menandatangani Kesepakatan Bersama (MoU) tentang Peningkatan Peran Lembaga Jasa Keuangan Dalam Perlindungan dan Pengelolaan Lingkungan Hidup Melalui Pengembangan Jasa Keuangan Berkelanjutan. Penandatanganan MoU dilakukan oleh Menteri Lingkungan Hidup, Prof. Dr. Balthasar Kambuaya, MBA dan Ketua Dewan Komisioner OJK, Muliaman D. Hadad. Kerjasama ini merupakan program lanjutan KLH dengan Bank Indonesia sejak tahun 2010 dalam kerangka pelaksanaan nota kesepahaman green banking. Kerjasama ini pun sejalan dengan komitmen KLH untuk mendorong pembangunan berkelanjutan yang berwawasan lingkungan sebagaimana yang diamanatkan dalam Undang-Undang No. 32 Tahun 2009 tentang Perlindungan dan Pengelolaan Lingkungan Hidup (UU PPLH). Pelaksanaan green banking adalah salah satu upaya untuk merubah paradigma dalam pembangunan nasional dari greedy economy menjadi green economy. Greedy economy merupakan istilah dimana fokus ekonomi hanya terbatas pada pertumbuhan ekonomi yang dinilai melalui pertumbuhan GDP, melakukan eksploitasi kekayaan alam, dan aktivitas ekonomi yang bertumpu pada hutang. Sedangkan green economy merupakan perubahan pandang terhadap pembangunan ekonomi dengan memperhatikan keseimbangan 3P (people, profit, planet), perlindungan dan pengelolaan kekayaan alam, serta partisipasi semua pihak.

Peran strategis OJK melalui keuangan berkelanjutan (Sustainable Finance) juga diharapkan menjadi bukti kongkrit dukungan lembaga jasa keuangan untuk mendukung pembangunan berkelanjutan berupa penyediaan sumber-sumber pendanaan proyek-proyek ramah lingkungan, seperti energi baru dan terbarukan, pertanian organik, industri hijau dan eco tourism. Berikut ini data hasil skoring terhadap bank yang dinilai berdasarkan kebijakan pemberian pinjaman terkait isu sosial dan lingkungan. 
Published July 2018

\section{EKONOMIKAWAN : Jurnal Ilmu Ekonomi dan Studi Pembangunan \\ ISSN : 1693-7600 (Print), ISSN : 2598-0157 (Online), http://jurnal.umsu.ac.Id/index.php/ekawan}

\section{Tabel 1}

Data Skoring Bank Berdasarkan Kebijakan Pemberian

Pinjaman Isu Lingkungan Sosial

\begin{tabular}{|l|c|}
\hline \multicolumn{1}{|c|}{ BANK } & SKOR \\
\hline HSBC & $37,83 \%$ \\
\hline Citibank & $36,08 \%$ \\
\hline The Bank of Tokyo - Mitsubishi UFJ & $19,81 \%$ \\
\hline Danamon & $10,98 \%$ \\
\hline BNI & $6,37 \%$ \\
\hline Bank Mandiri & $3,46 \%$ \\
\hline BRI & $3,09 \%$ \\
\hline Panin Bank & $2,95 \%$ \\
\hline BCA & $1,74 \%$ \\
\hline CIMB Niaga & $1,52 \%$ \\
\hline OCBC NISP & $1,13 \%$ \\
\hline
\end{tabular}

Sumber: http://finansial.bisnis.com.

Bank syariah sebagai lembaga yang menerapkan prinsip prinsip syariah, dimana syariah mengatur semua aspek kehidupan umat yang terdiri atas bukan saja menyangkut keimanan dan ibadah, tetapi juga aspek-aspek ekonomi, sosial dan budaya masyarakat. Dengan hubungan antar manusia dengan manusia lainnya, serta hubungan antara manusia dan alam. kemudian, muncul wacana tentang green banking sebagai salah satu upaya untuk merubah paradigma dalam pembangunan nasional dari greedy economymenjadi green economy, dimana perbankan sebagai lembaga keuangan mengambil peran pembiayaan bagi usaha-usaha produksi, diharapkan dapat melakukan filterisasi untuk mendukung ekonomi berkelanjutan yang ramah lingkungan. Dengan demikian dapat dianalisa bahwa prinsip prinsip syariah yang diterapkan oleh perbankan syariah memberi peran penting terhadap dukungan penerapan regulasi kelestarian alam yang dikeluarkan.

\section{METODE}

Jenis penelitian ini menggunakan Pendekatan Berpikir Sistem (Systetm Thinking Approach), yakni pendekatan organisatoris yang menggunakan ciri-ciri sistem sebagai titik tolak analisis. Pendekatan Berpikir Sistem memberikan penyelesaian masalah yang kompleks dengan metode dan alat yang mampu mengidentifikasi, menganalisis, mensimulasi dan mendisain sistem dengan komponen-komponen sistem yang saling terkait, yang diformulasikan secara lintas disiplin dan komplementer untuk mencapai tujuan yang sudah ditetapkan (Eriyatno, 2003). Sedangkan desain penelitian ini adalah Desain Eksplorasi (Exploratory Design) yakni desain penelitian yang dilakukan ketika tidak ada atau masih sedikitnya kajian penelitian yang dilakukan atas suatu masalah. Desain ini menggunakan analisis kualitatif dan didukung oleh analisis kuantitatif. Kedua analisis tersebut dapat digunakan secara bersamaan karena saling melengkapi. (Stainback (1988) dalam Sugiyono (2010). Data penelitian adalah data sekunder yang diperoleh dari data literatur yang mendukung dan diperoleh dari website ojk. 
Published July 2018

E⿹丁口

EKONOMIKAWAN : Jurnal Ilmu Ekonomi dan Studi Pembangunan

ISSN : 1693-7600 (Print), ISSN : 2598-0157 (Online), http://jurnal.umsu.ac.ld/index.php/ekawan

Teknik Pemodelan dilakukan guna menghasilkan suatu formulasi struktur model yang menyerupai sifat-sifat dan perilaku sistem dunia nyata yang kompleks, tetapi dalam bentuk (pola) yang sederhana. Melalui penyederhanaan sistem dunia nyata ke dalam suatu struktur model, maka tingkah-laku elemen-elemen yang menyusun sistem dan interaksi antara satu elemen dengan elemen yang lain di dalam sistem dapat dipelajari dan dianalisis.

Teknik Simulasi dilakukan untuk melihat kesesuaian perilaku keluaran model dengan data hitoris dan untuk mempelajari konsekuensi yang dihasilkan oleh perilaku dinamis dari suatu sistem. Simulasi terhadap uji statistik parameter adalah untuk mengevaluasi kualitas dan validitasnya. Hasil simulasi akan memperlihatkan apakah model sistem tersebut merupakan perwakilan yang sahih (valid) dari realitas yang dikaji dan dapat menghasilkan kesimpulan yang meyakinkan. Sedangkan simulasi terhadap skenarioskenario kebijakan dimaksudkan untuk analisis sensitivitas guna mendapatkan gambaran keputusan kebijakan yang terbaik.

\section{HASIL PENENLITIAN DAN PEMBAHASAN}

\section{Implementasi Green Banking Perbankan Syariah}

Green Banking merupakan istilah umum yang mengacu pada praktek-praktek dan pedoman bank-bank dalam pembangunan yang berkelanjutan di bidang ekonomi, lingkungan, dan sosial. Konsep "Green Banking" atau "Perbankan Hijau" adalah sebuah konsep yang mendorong bisnis perbankan membantu pengurangan pencemaran lingkungan. Untuk membantu pengurangan pencemaran lingkungan, bank dalam proses pembiayaan sebuah pembangunan harus melihat dampak terhadap kelestarian lingkungan (Broto Rauth Bhardwaj dan Aarushi Malhotra. 2013).

Konsep green banking ini sangat erat kaitannya dengan istilah green financing. Green financingdapat diartikan sebagai fasilitas pinjaman dari lembaga keuangan kepada debitur yang bergerak di sektor bisnis yang tidak berdampak pada penurunan kualitas lingkungan maupun kondisi sosial masyarakat. Meski demikian, green banking tidak hanya berkutat pada dunia pembiayaan, namun juga program-program lain yang berwawasan lingkungan (Ajeng Radyati).

Pemberian pembiayaan oleh perbankan syariah dapat merupakan suatu masalah bila pembiayaan itu dipergunakan untuk usaha ataupun kegiatan yang pada akhirnya menimbulkan atau mengakibatkan pencemaran atau perusakan lingkungan hidup. Dalam hal ini seharusnya badan-badan atau lembaga-lembaga keuangan yang memberikan pembiayaan dapat digerakkan untuk berperan serta dalam pengelolaan lingkungan hidup, karena perusahaan yang ingin berkembang tergantung pada fasilitas pembiayaan.

Dengan demikian dalam pembiayaan perbankan, analisis resiko tidak hanya terbatas pada analisis berdasarkan kinerja proyek, tetapi juga memerlukan metode analisis yang memperhitungkan biaya-biaya eksternal (benefit and risk analysis) yang melibatkan berbagai disiplin ilmu (inter and multidicipline science), khususnya untuk memahami lingkungan hidup. Dengan berlakunya undang-undang Perbankan dan sebagai akibat dari pelaksanaan prinsip kehati-hatian (prudent banking) serta masalah tingkat kesehatan bank, sektor perbankan tentunya akan sangat concern kepada masalah lingkungan. 
Pihak perbankan dalam memberikan pembiayaan tidak menginginkan proyek yang dibiayainya menimbulkan pencemaran lingkungan, misalnya sampai menimbulkan keresahan masyarakat. Oleh karena bank syariah sebagai pemberi pembiayaan akan diminta pertanggungjawabannya, dalam hal ini penilaianterhadap analisa lingkungan serta dampak lingkungannya. Namun demikian resiko kerusakan lingkungan yang timbul akibat sebuah proyek yang dapat diantisipasi sejak awal.

Dalam Pasal 22 ayat (2) UPPLH, untuk menentukan suatu kegiatan yang memiliki dampak penting terhadap lingkungan hidup ditentukan oleh :

a Jumlah manusia yang akan terkena dampak;

b Luas wilayah persebaran dampak;

c Intensitas dan lamanya dampak berlangsung;

d Banyaknya komponen lingkungan lainnya yang terkena dampak;

e Sifat kumulatif dampak tersebut;

f Berbalik (reversible) atau tidak berbaliknya (irreversible) dampak.

g Kriteria lain sesuai dengan perkembangan ilmu pengetahuan dan teknologi.

Berkaitan dengan hal tersebut di atas, sektor perbankan dalam membiayai proyek industri secara umum dapat mengkaji hal-hal sebagai berikut :

a) ada hal-hal yang berbahaya terhadap kesehatan yang berkaitan dengan proses industrinya;

b) akan terjadi gangguan yang cukup berarti terhadap masyarakat;

c) ada potensi konflik dengan kepentingan lainnya;

d) perlunya penambahan pembangunan infrastruktur termasuk transport dan pembangkit tenaga listrik yang ada;

e) proyek industri sudah memiliki instalasi pengolahan limbah atau belum Keseluruhan itu perlu dikaji karena sektor perbankan yang berfungsi sebagai intermediary dalam pembangunan telah melakukan mobilisasi dana masyarakat dan menyalurkan dana tersebut antara lain berupa pembiayaan pada industriindustri dalam proses pembangunannya. Penjabaran pelaksanaan wawasan tersebut tercermin pada Pasal 22 ayat (1) UUPPLH.

Pencantuman klausul-klausul tentang lingkungan hidup bukan hanya peran serta bank dalam mengelola lingkungan, tetapi juga :

1. Dapat menguntungkan bank, seandainya pihak debitur dalam usahanya telah mencemarkan lingkungan, setidaknya dari turut serta bertanggungjawab atas pencemaran yang ditimbulkan perusahaan debitur.

2. Dalam skala yang lebih luas, jika semua bank melakukan tindakan yang sama setidaknya akan mengurangi pencemaran lingkungan hidup, karena jika pencantuman klausul tersebut merupakan syarat yang harus dipenuhi yang tidak dapat ditawar lagi, maka akan memberikan dampak positif dalam rangka mencegah terjadinya pencemaran lingkungan hidup secara luas.

Pencantuman klausul pencegahan pencemaran lingkungan hidup bukan hanya sekedar pelengkap isi perjanjian pembiayaan, tetapi juga harus disertai dengan pihak instansi terkait yang mengawasi agar tidak terjadi pencemaran lingkungan hidup, artinya harus ada tindak lanjut dan kerjasama dengan pihak lain yang diberi tugas untuk mengawasi masalah lingkungan hidup, dengan kata lain bahwa klausul-klausul tersebut harus dilaksanakan/ditegakkan atau diterapkan sebagaimana mestinya, sesuai dengan maksud dan tujuan dicantumkannya klausul-klausul tersebut. 
Published July 2018

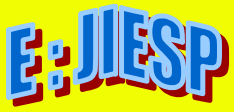

EKONOMIKAWAN : Jurnal Ilmu Ekonomi dan Studi Pembangunan

ISSN : 1693-7600 (Print), ISSN : 2598-0157 (Online), http://jurnal.umsu.ac.ld/index.php/ekawan

Dalam mengarahkan kebijaksanaan pembiayaan yang berwawasan lingkungan, contoh ketentuan yang harus diajukan kepada calon debitur dalam proses pemberian dan persetujuan pembiayaannya yaitu:

1. AMDAL sebagai persyaratan perizinan atas setiap kegiatan yang mempunyai dampak penting terhadap lingkungan/lingkungan hidup.

2. Keputusan persetujuan atas Rencana Pengelolaan Lingkungan (RKL) dan Rencana Pemantauan Lingkungan (RPL) sesuai dengan syarat-syarat.

3. Surat pernyataan lingkungan dari perusahaan/calon debitur.

4. Internal monitoring, yaitu kegiatan pemantauan yang dilakukan oleh perusahaan/debitur secara cermat keadaan fasilitas, pengoperasian dan pengaruh terhadap lingkungan serta melaporkannya secara berkala, baik kepada pemerintah maupun bank.

5. Inspection/trade checking, yaitu kegiatan pemantauan yang dilakukan oleh bank syariah untuk melihat sejauh mana ketaatan dan pengoperasian serta pengaruh terhadap lingkungan. Oleh komite pembiayaan hal ini dilaporkan sebagai laporan hasil kunjungan debitur.

\section{Peran dan Tanggung Jawab perbankan syariah dalam penegakan Green Banking dalam kebijakan penyaluran pembiayaan}

Fungsi utama perbankan syariah adalah menghimpun dana dari masyarakat dan penyalur dana masyarakat. Akan tetapi sektor perbankan syariah dalam partisipasinya memberikan pembiayaan pembangunan tetap harus memperhatikan prinsip kehatihatian, antara lain feasibility study, viability, serta profitability atas dasar repayment capacity. Tujuannya adalah untuk menunjang pelaksanaan pembangunan nasional dalam rangka meningkatkan pemerataan, pertumbuhan ekonomi dan stabilitas nasional ke arah peningkatan kesejahteraan rakyat.

Pembiayaan proyek yang berwawasan lingkungan telah terbukti dapat meningkatkan daya saing dan memberi keunggulan tersendiri bagi bank-bank yang menerapkannya sebagai strategi bisnis. Dengan demikian, perbankan syariah diharapkan dapat meningkatkan peran dan perhatian terhadap pembiayaan kepada proyek-proyek yang mempunyai perhatian terhadap peningkatan kualitas lingkungan hidup (Sambutan Burhanuddin Abdullah Gubernur BI, 2004).

Usaha perbankan syariah sesungguhnya tidak mempunyai keterkaitan langsung dengan lingkungan, namun demikian Bank Indonesia dalam hal ini OJK dengan berbagai ketentuan dan peraturan yang dikeluarkannya, dapat mendorong peningkatan peran perbankan syariah dalam meningkatkan kualitas pengelolaan lingkungan hidup. Apabila industri yang dibiayai oleh bank syariah berjalan baik dan tidak menimbulkan dampak negatif terhadap lingkungan, maka hasil pendapatan bagi hasil dari pembiayaan yang diberikan dapat berjalan sesuai dengan cash flow bank syariah tersebut. Demikian pula return capacity dari pembiayaan yang diberikan pada industri tersebut dapat dijamin kolektibilitasnya. Jika semua sektor industri yang dibiayai bank syariah tidak memiliki dampak negatif yang berarti maka dapat diharapkan pembiayaan bank syariah pada sektor industri akan meningkat pula. 
Published July 2018

Hal ini menunjukkan bahwa operasional perbankan syariah sangat terpengaruh oleh perkembangan sektor yang dibiayai. Peran dan tanggung jawab perbankan syariah dalam penegakan hukum lingkungan dimana perbankan syariah dapat mendorong nasabah debitur untuk lebih serius memperhatikan aspek lingkungan.

Kelalaian bank syariah dalam memperhatikan aspek lingkungan hidup akan dapat menimbulkan kerugian bagi bank, baik karena kerugian yang timbul akibat merosotnya nilai barang jaminan, ditutupnya usaha nasabah debitur maupun akibat gugatan terhadap bank syariah sendiri. Kenyataan yang dihadapi sekarang ini adalah dunia perbankan syariah masih belum sepenuhnya memperhatikan aspek lingkungan.

Berdasarkan uraian tersebut di atas maka peran dan tanggung jawab perbankan syariah dalam pelaksanaan hukum perkreditan berwawasan lingkungan, bank syariah perlu melakukan antisipasi terhadap potensi pencemaran dalam kegiatan usaha calon nasabah debitur, setidak-tidaknya karena tiga hal, yaitu sebagai pemegang pembiayaan, ikut dalam manajemen dan demi keamanan atau kelancaran pembayaran pembiayaan itu sendiri.

OJK berada pada posisi yang sangat penting dalam memberikan pedoman bagi bank-bank pembangunan dan lembaga keuangan bukan bank untuk mendorong bahkan mewajibkan bank-bank memberikan pedoman sangat penting karena lembaga perbankan menempati posisi yang strategis dalam "memaksa" kalangan usaha peduli pada aspek perlindungan daya dukung lingkungan, keselamatan, serta kesejahteraan orang banyak.

Dalam rangka penerapan AMDAL, bank syariah harus meneliti bahwa proyek yang dibiayai tidak bertentangan dengan tatanan lingkungan yang ada. Apabila dampak negatifnya cukup besar, bank syariah harus mengkaji apakah industri itu memiliki plant treatment untuk pencegahan kerusakan lingkungan atau tidak. Bank syariah dapat menolak proposal pemrakarsa, apabila proyek tersebut tidak memiliki sarana pengolahan limbah yang baik.

Kewajiban hukum dan moral setiap bank syariah di Indonesia untuk ikut mengelola lingkungan hidup, sekalipun secara tidak langsung, seyogyanya tidak terbatas hanya kepada melakukan analisis lingkungan hidup atas permohonan pembiayaan calon nasabah debitur saja, tetapi kiranya dapat berlanjut terus sampai pembiayaan yang telah diberikan atau dilunasi oleh nasabah. OJK belum mewajibkan bank-bank untuk melakukan analisis lingkungan hidup dalam rangka mempertimbangkan permohonan pembiayaan dari calon nasabah debitur. Baru sebatas tahap sebelum pembiayaan diberikan. Setelah pembiayaan diputuskan pemberiannya oleh bank syariah dan selama pembiayaan itu digunakan oleh nasabah debitur, sama sekali belum diatur oleh OJK, saat in diharapkan dalam road map perbankan syariah mengacu pada suistainable financing.

Selain daripada melakukan analisis mengenai dampak lingkungan hidup pada setiap mempertimbangkan pemberian pembiayaan, bank syariah dapat juga ikut berpartisipasi dalam upaya pengelolaan lingkungan hidup. Bank syariah dapat melakukan hal-hal sebagai berikut:

a mencantumkan klausul-klausul lingkungan hidup di dalam perjanjian pembiayaan. 
Published July 2018

Fill

EKONOMIKAWAN : Jurnal Ilmu Ekonomi dan Studi Pembangunan

ISSN : 1693-7600 (Print), ISSN : 2598-0157 (Online), http://jurnal.umsu.ac.ld/index.php/ekawan

b dapat memberikan jaminan bahwa nasabah debitur telah memiliki izin-izin yang diperlukan dari instansi yang berwenang yang berkaitan dengan pengelolaan lingkungan hidup sesuai dengan peraturan perundangundangan yang berlaku.

c melakukan pemantauan selama pembangunan proyek yang dibiayai dengan pembiayaan bank syariah itu, untuk memastikan apakah sarana-sarana yang diperlukan oleh proyek dalam rangka mencegah perusakan dan pencemaran lingkungan hidup telah dibangun sebagaimana mestinya. Pelanggaran mengenai hal itu kiranya dapat dikategorikan sebagai event of default dari perjanjian pembiayaan, yang dengan demikian memberikan hak kepada bank syariah untuk menghentikan penarikan lebih lanjut oleh nasabah debitur dan atas pembiayaan itu seketika itu pula menagih nasabah debitur untuk melunasi pembiayaan itu;

d memantau nasabah debitur tidak melakukan perusakan atau pencemaran lingkungan hidup disekitar proyek itu berdiri dengan memastikan bahwa proyek nasabah debitur itu tidak membuang atau menyimpan zat-zat berbahaya disekitar proyek.

\section{Prinsip-prinsip perbankan syariah dalam green banking}

Bank syariah sudah seharusnya berada pada barisan terdepan dalam pelaksanaan kebijakan green banking dan green economy saat ini, sejumlah bank syariah memang sudah aktif dalam penyediaan pembiyaan usaha pembangunan energi baru dan terbarukan, pembiayaan peningkatan efisiensi energi industri, pembiayaan pertanian terpadu ramah lingkungan. Green banking dalam bank syariah didasarkan pada strategi pembiayaan proyek atau usaha ramah lingkungan dan ramah sosial yang mana sasarannya adalah pemeliharaan kelestarian lingkungan hidup dan stabilitas sosial masyarakat. Prinsip-prinsip tersebut adalah:

a Adalah

Menempatkan sesuatu hanya pada tempatnya, dan memberikan sesuatu hanya pada yang berhak serta memperlakukan sesuatu sesuai posisinya. Dalam dukungannya terhadap regulasi green economy yakni memberi batasan kepada perusahaan untuk mengelola limbahnya atau perbankan syariah tidak mendukung produksi perusahaan yang acuh tak acuh dalam pengelolaan limbah sehingga menimbulkan ketidak adilan bagi masyarakat setempat yang terkena imbas limbah dari peruahaan terebut. Hal ini sesuai dengan isi tujuan pelestarian lingkungan hidup dalam UU No. 32 Tahun 2009 pada bagian:(a.)melindungi wilayah Negara Kesatuan Republik Indonesia dari pencemaran dan/atau kerusakan lingkungan hidup; (b.)menjamin keselamatan, kesehatan, dan kehidupan manusia; (c.)menjamin kelangsungan kehidupan makhluk hidup dan kelestarian ekosistem; dan (d.)mengendalikan pemanfaatan sumber daya alam secara bijaksana; 
Published July 2018

EKONOMIKAWAN : Jurnal Ilmu Ekonomi dan Studi Pembangunan

ISSN : 1693-7600 (Print), ISSN : 2598-0157 (Online), http://jurnal.umsu.ac.Id/index.php/ekawan

b Tawazun

Adalah keseimbangan aspek material dan spiritual, aspek privat dan publik, sektor keuangan dan sektor riil, bisnis dan sosial, dan keseimbangan aspek pemanfaatan dan kelestarian. Dalam dukungannya terhadap regulasi green economy yakni perusahaan dibatasi dalam memproduksi agar tidak melakukan eksploitasi. Hal ini sesuai dengan isi tujuan pelestarian lingkungan hidup dalam UU No. 32 Tahun 2009 pada bagian:mencapai keserasian, keselarasan, dan keseimbangan lingkungan hidup;

c Mashlahah

Segala bentuk kebaikan yang berdimensi duniawi dan ukhrowi, material dan spiritual serta individual dan kolektif serta harus memenuhi 3 unsur, yakni:

1). Kepatuhan syariah (halal)

2). Bermanfaat dan

3). Membawa kebaikan (tayyib).

Dengan prinsip syariah ini, memberi dukungan untuk tidak membiayai perusahaan yang memproduksi barang tidak halal, membawa keburukan dan tidak bermanfaat. Hal ini sesuai dengan isi tujuan pelestarian lingkungan hidup dalam UU No. 32 Tahun 2009 pada bagian:mewujudkan pembangunan berkelanjutan; dan mengantisipasi isu lingkungan global.

d Alamiyah

Sesuatu yang dapat dilakukan dan diterima oleh, dengan, dan untuk semua pihak yang berkepentingan (stakeholders), tanpa membedakan suku, agama, ras, dan golongan, sesuai dengan semangat kerahmatan semesta (rahmatan lil alamin). Prinsip ini menjadi berperan untuk tidak memberlakukan apapun dan siapapun secara semena-mena, termasuk lingkungan hidup, flora, dan fauna. Hal ini sesuai dengan isi tujuan pelestarian lingkungan hidup dalam UU No. 32 Tahun 2009 pada bagian:menjaga kelestarian fungsi lingkungan hidup.

e Zalim

Transaksi menimbulkan ketidakadilan bagi pihak lainya. Artinya dalam akad tersebut di satu pihak lebih banyak hanya menentukan hak-hak pihak yang berposisi kuat dengan kurang menentukan yang menjadi kewajiban-kewajibannya kepada pihak lainnya, sebaliknya dalam akad tersebut lebih banyak mengatur kewajiban-kewajiban pihak lain yang posisinya lemah dan kurang menentukan apa hak-haknya terhadap pihak lainnya. Hal ini sesuai dengan isi tujuan pelestarian lingkungan hidup dalam UU No. 32 Tahun 2009 pada bagian: yakni menjamin terpenuhinya keadilan generasi masa kini dan generasi masa depan; menjamin pemenuhan dan perlindungan hak atas lingkungan hidup sebagai bagian dari hak asasi manusia.

Dari pemaparan diatas, dapat diketahui bahwa prinsip-prinsip syariah relevan dan tidak bertentangan dengan tujuan regulasi green economy, bahkan jauh dari sebelum adanya wacana green economy prinsip-prinsip syariah sebenarnya telah mengambil peran besar dalam pelestarian atau penjagaan lingkungan. Tentunya, regulasi green economy ini disambut baik oleh perbankan syariah karena sesuai dengan prinsipprinsipnya. 
Published July 2018

Oleh karena itu, semestinya ini memberi kekuatan baru bagi perkembangan bank syariah dimana seharusnya bank syariah tersebut dapat menjadi pelopor dan acuan terdepan dalam pengaplikasian green economy dan green banking, misal dalam kebijakan pembiayaan dan prosedur operasional bank syariah, mekanisme screening pembiayaan dan investasi menetapkan negative list usaha haram seperti alkohol, persenjataan, perjudian, usaha berdampak kerusakan moralitas, juga kegiatan bisnis nyata yang berdampak mengancam sustainabilitas kelestarian lingkungan hidup. Oleh karenanya, prinsip syariah mengambil peran penting dan besar untuk mendukung gerakan pelestarian lingkungan.

Otoritas Jasa Keuangan (OJK) menyatakan delapan lembaga jasa keuangan perbankan telah berkomitmen berkomitmen untuk menjadi penggerak utama dalam pembiayaan proyek hijau atau greenbanking. Ketua Dewan Komisioner OJK Muliaman D Hadad mengatakan komitmen tersebut dituangkan dalam penandatanganan green banking pilot project oleh delapan perbankan yaitu Bank Mandiri, BRI, BCA, BNI, Bank Muamalat, BRI syariah, BJB dan Bank Artha Graha Internasional.

Adapun penerapannya dinegara lain, pada tahun 2011 UNEP FI mengeluarkan laporan terhadap perkembangan bank-bank yang bernaung di bawahnya. Bank-bank tersebut tersebar dari berbagai negara dan menjalankan program-program perbankan yang berdaya dukung terhadap lingkungan, diantaranya yaitu (United Nations Environment Programme Finance Initiative. 2011. UNEP FI Guide to Banking \& Sustainability) adalah sebagai berikut:

\section{Brazil}

Pada tahun 2009 asosiasi perbankan Brasil, Febraban, menandatangani perjanjian "Protokol Hijau" (Protocolo Verde) dengan Kementerian Lingkungan Hidup mereka. Komitmen yang dibuat di bawah Protokol ini meliputi promosi lingkungan sosial, pengelolaan dan peningkatan kesadaran terhadap lingkungan hidup. Indikator kepatuhan terhadap Protokol ini dikembangkan bersama oleh bank-bank, pemerintah dan LSM di bawah naungan asosiasi perbankan Brasil.

\section{Bangladesh}

Pada bulan Januari 2011, Bank Sentral Bangladesh mengambil langkah proaktif mempromosikan isu-isu lingkungan hidup dan sosial dalam keuangan negara, dengan mengeluarkan Pedoman Manajemen Resiko Lingkungan untuk Bank dan Lembaga Keuangan dan selanjutnya menetapkan pedoman Kebijakan Green Banking di Bangladesh. Kebijakan Green Banking itu mewajibkan bagi bank-bank yang ada di Bangladesh untuk mengatasi masalah lingkungan dan sosial melalui proses pinjaman, mengembangkan kerangka kerja, melatih staf dan mulai melaporkan isu-isu lingkungan dan sosial. 
Published July 2018

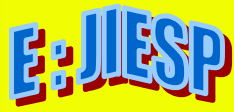

EKONOMIKAWAN : Jurnal Ilmu Ekonomi dan Studi Pembangunan

ISSN : 1693-7600 (Print), ISSN : 2598-0157 (Online), http://jurnal.umsu.ac.ld/index.php/ekawan

\section{Cina}

Pada tahun 2007, Bank Rakyat China (Bank Sentral), Komisi Regulator Perbankan China dan Departemen Perlindungan Lingkungan Hidup Cina bersama-sama meluncurkan Kebijakan Kredit Hijau. Kebijakan ini mendesak lembaga keuangan untuk mengintegrasikan isu-isu lingkungan dalam kegiatan mereka, terutama dalam bentuk penarikan pinjaman dari perusahaan industri yang mempunyai konsumsi tinggi pada energi dan menghasilkan polusi yang tinggi. Sebaliknya memberi dukungan finansial untuk industri ramah lingkungan. Sejak itu bank-bank Cina mulai aktif mencari dan memahami masalah lingkungan serta implikasinya, dengan tujuan untuk menerapkan kebijakan ini.

\section{Kanada}

Toronto Dominion Bank di Kanada telah mengembangkan dua program yang paralel di mana karyawan mengambil alih tanggung jawab untuk memperbesar kesadaran tentang isu-isu lingkungan, sehingga meningkatkan keterlibatan karyawan di seluruh organisasi. Dua program itu yaitu:

1. Retail Operations: Relawan-relawan dalam program ini disebut Green Koordinator bertanggung jawab untuk meningkatkan kesadaran kepada karyawan tentang isu-isu lingkungan dalam mereka cabang. Mereka juga bekerja memberi informasi mengenai inisiatif lingkungan. Mengingat bahwa mereka berada di garis depan operasional bank, mereka mampu menjangkau basis pelanggan dan menginformasikan tentang kredensial bank terhadap pengelolaan lingkungan.

2. Business units and sub-units: Relawan yang sukses dalam menjalankan Retail Operations akan diberi gelar Duta Lingkungan dalam perusahaan. Duta Lingkungan ini bertugas mengatur mekanisme untuk melibatkan karyawan dalam program lingkungan perusahaan. Duta Lingkungan juga diberi kewenangan untuk mengadakan komite lingkungan untuk mengatur strategi dan melaksanakan ide-ide mereka.

\section{Yunani}

Piraeus Bank di Yunani menyediakan jasa konsultasi dan pendanaan untuk klien mereka yang ingin menerapkan kebijakan pembangunan berkelanjutan. Bank ini melakukan road show di kota-kota besar di seluruh Yunani untuk memberi informasi bagaimana cara menjalankan sebuah bisnis ramah lingkungan dan membantu perusahaan yang sudah ada tentang cara beradaptasi terhadap perubahan iklim. Selain itu, Bank ini juga memberi panduan pada tingkat perusahaan bagaimana cara mengubah strategi bisnis dalam rangka untuk mengurangi resiko perubahan iklim. 
Published July 2018

EKONOMIKAWAN : Jurnal Ilmu Ekonomi dan Studi Pembangunan

ISSN : 1693-7600 (Print), ISSN : 2598-0157 (Online), http://jurnal.umsu.ac.Id/index.php/ekawan

\section{Sinergi dan Optimalisasi Green Banking Perbankan Syariah dalam Mewujudkan Suistainable Finance}

Konsep green economy telah sejalan dengan konsep ekonomi syariah. Implementasi konsep green economy dalam masalah pembangunan yang tidak mengindahkan aspek lingkungan maka lahirlah konsep green building sebagai respon terhadap krisis energi dan keprihatinan masyarakat tentang lingkungan hidup. Green building sering dikenal sebagai sustainable building atau bangunan berkelanjutan yang berwawasan lingkungan. Struktur green building dirancang, dibangun, direnovasi dan dioperasikan untuk panduan hemat energi, dan memberi dampak positif bagi lingkungan, dampak ekonomi dan sosial. Elemen utama dalam konsep green building yakni memperhatikan unsur material, energi dan faktor kesehatan.

Pengembangan Green Building memerlukan peranan perbankan, dalam hal ini peran perbankan syariah adalah dalam bentuk penerapan Green Banking. Perbankan syariah diharapkan lebih berfokus pada pemberian pembiayaan pada usaha-usaha yang tidak mengakibatkan kerusakan lingkungan, mengarah ke bisnis yang berkelanjutan dan diterima masyarakat, tidak mengeksploitasi tenaga kerja dengan membayar upah rendah, tidak menggunakan tenaga kerja di bawah umur, tidak menghasilkan produk yang berbahaya, perusahaan yang terlibat dalam konservasi dan daur ulang, menjalankan etika dalam berusaha, tidak terlibat dalam pelanggaran hak asasi manusia, tidak terlibat dalam pornografi, perjudian, alkohol dan tembakau, serta tidak terlibat dalam persenjataan dan pembuatan senjata nuklir.

Sebagai salah satu pemberi dana, bank syariah tidak saja hanya melihat pertimbangan ekonomisnya, tetapi juga keterpaduan dengan lingkungannya. Dengan demikian perbankan tidak ikut membiayai proyek-proyek yang diperkirakan akan dapat menimbulkan dampak yang merugikan ekosistem.

Pada sistem perbankan syariah, dengan pertimbangan faktor-faktor keseimbangan lingkungan akan mengeliminisasikan resiko-resiko dalam pemberian pembiayaannya kepada nasabah debitur. Untuk itu perlu dikembangkan suatu kemampuan analisis resiko lingkungan secara ekologis dapat dipertanggungjawabkan. Karenanya dalam memasuki era pembangunan yang bertumpu pada teknologi untuk memprediksi terjadinya resiko kerugian diperlukan keahlian dalam kecermatan yang akurat. Dengan demikian dalam pembiayaan perbankan syariah, analisis resiko tidak hanya terbatas pada analisis berdasarkan kinerja proyek, tetapi juga memerlukan metode analisis yang memperhitungkan biaya-biaya eksternal (benefit and risk analysis) yang melibatkan berbagai disiplin ilmu(inter and multidicipline science), khususnya untuk memahami lingkungan hidup.

Dengan berlakunya undang-undang perbankan syariah dan sebagai akibat dari pelaksanaan prinsip kehati-hatian (prudent banking) serta masalah tingkat kesehatan bank, sektor perbankan syariah tentunya akan sangat concern kepada masalah lingkungan. Pihak perbankan syariah dalam memberikan pembiayaanya tidak menginginkan proyek yang dibiayainya menimbulkan pencemaran lingkungan, misalnya sampai menimbulkan keresahan masyarakat. Oleh karena bank syariah sebagai pemberi pembiayaan akan diminta pertanggungjawabannya, dalam hal ini penilaian terhadap analisa lingkungan serta dampak lingkungannya. Namun demikian resiko kerusakan lingkungan yang timbul akibat sebuah proyek yang dapat diantisipasi sejak awal. 
Published July 2018

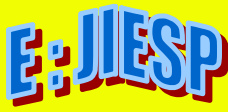

EKONOMIKAWAN : Jurnal Ilmu Ekonomi dan Studi Pembangunan

ISSN : 1693-7600 (Print), ISSN : 2598-0157 (Online), http://jurnal.umsu.ac.Id/index.php/ekawan

Apabila tidak dipertimbangkan dampaknya akan dapat mengakibatkan penutupan proyek tersebut dengan tuduhan telah merusak lingkungan. Dalam hal ini terjadinya penutupan sebuah proyek akibatnya akan menimbulkan kesulitan keuangan pada proyek itu. Akhirnya pembiayaan bank syariah yang telah dikucurkan sebagaimana yang diketahui akan dapat mengakibatkan kesulitan likuiditas bank yang bersangkutan, yang berakibat pula pada turunnya tingkat kesehatan bank tersebut. Bagi bank yang dikelola dengan baik, tentu tidak akan mau menempuh resiko-resiko yang bisa menyebabkan turunnya tingkat kesehatannya.

Dari penjelasan di atas ternyata undang-undang Perbankan secara eksplisit telah mencantumkan kewajiban perbankan di Indonesia untuk melaksanakan perbankan hijau (Green Banking) dan hal ini sesuai dengan gerak langkah yang dibutuhkan perbankan nasional untuk berperan serta dan bertanggungjawab dalam pelestarian fungsi lingkungan guna melaksanakan pembangunan berwawasan lingkungan seperti yang diamanatkan dalam propenas Tahun 2000-2004 dan menjadi semakin jelas. Dengan mengesampingkan aspek lingkungan justru dapat mengakibatkan resiko menurunnya tingkat kesejahteraan rakyat.

Pembiayaan proyek yang berwawasan lingkungan telah terbukti dapat meningkatkan daya saing dan memberi keunggulan tersendiri bagi bank-bank yang menerapkannya sebagai strategi bisnis. Dengan demikian, perbankan syariah diharapkan dapat meningkatkan peran dan perhatian terhadap pembiayaan kepada proyek-proyek yang mempunyai perhatian terhadap peningkatan kualitas lingkungan hidup.

Bank, lingkungan, dan pembangunan merupakan tiga unsur penting yang kualitasnya selalu diharapkan untuk terus meningkat. Kualitas dan kinerja bank syariah tentulah akan ikut menentukan kondisi perekonomian Negara ini, lebih khusus lagi dapat memberi kontribusi yang besar terhadap pembangunan dalam arti yang luas, karena bank syariah adalah agen pembangunan (agent of development). Dengan begitu pembangunan diharapkan dapat terus berjalan sesuai dengan target-target yang diharapkan oleh seluruh stakeholder bangsa ini. Tentunya yang diharapkan adalah pembangunan yang berkelanjutan (suistanable development).

Pembiayaan hijau (green financing) sudah mulai digaungkan oleh Bank Indonesia dan KLH dalam MOU tanggal 17 Desember 2010 dalam terma "green banking", yakni suatu konsep pembiayaan dan produk-produk jasa perbankan lainnya yang mengutamakan aspek-aspek keberlanjutan, baik ekonomi, lingkungan sosial-budaya, maupun teknologi, secara bersamaan. Langkah awal ini perlu diapresiasi dan segera ditindaklanjuti ke seluruh perbankan syariah sebelum ekosistem hancur berantakan, entropik (irreversible) dan berubah menjadi bencana mengerikan. Dalam Pasal 47 UU Perlindungan dan Pengelolaan Lingkungan Hidup No.32 tahun 2009, terdapat paragraf analisis risiko lingkungan hidup. Analisis seperti ini sebaiknya diperluas bukan hanya ke pelaku usaha namun juga diterapkan ke pihak lain yang berhubungan dengan pelaku usaha, khususnya perbankan atau investor lainnya. Kewajiban Pemerintah bersama Regulator (BI, Depkeu) untuk menurunkannya di level praksis perbankan yang juga mencakup investasi yang bertanggungjawab terhadap lingkungan. 
Published July 2018

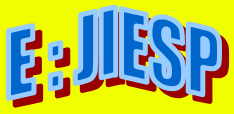

EKONOMIKAWAN : Jurnal Ilmu Ekonomi dan Studi Pembangunan

ISSN : 1693-7600 (Print), ISSN : 2598-0157 (Online), http://jurnal.umsu.ac.Id/index.php/ekawan

Untuk mewujudkan praktek "green financing" dan "green banking" secara komprehensif maka selain regulator, peran nasabah dan pemegang saham sangat dibutuhkan. Suara kedua stakeholder khususnya mereka yang peduli pada isuisu sustainability (keberlanjutan) dapat mempercepat manajemen senior menyesuaikan bisnis banknya dengan lingkungan hidup.

Green economic selama ini dijalankan dalam sistem perbankan syariah dalam bentuk green banking, dimana orientasi dari bank syariah tidak hanya sekedar mengejar profit oriented dari para pemegang saham saja tapi juga memberikan perlindungan kepada peran konsumen dan nasabah. Paradigma inilah yang selama ini dijalankan, dengan demikian peran perbankan syariah memberikan keseimbangan secara berkelanjutan. Kemakmuran bisa meningkat bila tidak mengabaikan kepentingan masyarakat dengan demikian distribusi kesejahteraan tidak mengalami ketergangguan dan jika ini terjadi maka pembangunan berkelanjutan seperti dalam green economic bisa terwujud. Orientasi ini menjadi dominan dalam green bank itu sendiri di bank syariah.

Tiga filosofi dasar ekonomi Islam seperti dalam fundasinya, pilar dan tujuannya memberikan orientasi pada green economic. Hal ini nampak ketika tujuan dari filosofi ekonomi syariah yakni menuju sasaran utama yaitu falah, dimana didalamnya terdiri pada kesejahteraan spiritual dan material. Untuk itu dalam membangun semua itu perlu kesadaran dan integritas disinilah dalam mengelola perbankan perlu sebuah good corporate governance dan tata kelola perbankan yang dibentuk dari dasar agama. Dengan dasar inilah mengembangkan perbankan syariah dalam fondasinya dilakukan atas dasar kebaikan secara muamalah dan dukungan dari berbagai elemen baik itu peran masyarakat,pengusaha dan perbankan dalam mengembangkan konsep pembangunan ekonomi hijau yang berkelanjutan untuk kehidupan yang lebih baik.

\section{Bank Syariah menjadi Pelaku Utama Green Banking dalam mewujudkan Suistainable Finance}

Perbankan syariah sebagai pelaku pembangunan berarti bahwa itu adalah salah satu lembaga keuangan yang menerapkan prinsip ekonomi demokrasidi dalamnyaKegiatan, dan salah satu prinsipnya adalah pembangunan berkelanjutan dan ekologi. Jadi, semua aktivitas perbankan syariah harus mencerminkan prinsip itu.Perbankan syariah adalah Lembaga keuangan berfungsi memperlancar ekonomi mekanisme secara nyata sektor Kegiatan usaha gadai (investasi, pembelian, atau lainnya) berdasarkan prinsip syariah.

Pembangunan berkelanjutan seperti telah dijelaskan sebelumnya, artinya proses pembangunan diharapkan bisa memenuhi kebutuhan masyarakat saat ini tanpa membahayakan kemampuan generasi penerus untuk memenuhi kebutuhan mereka di masa depan, memanfaatkan potensi sumber daya alam untuk kehidupan. Hal ini sejalan dengan bank syariah dimana memberi pembiayaan yang produktif untuk nasabahnya, pembiayaan produktif yaitu sejalan dengan perkembangan bisnis bank syariah ikut sertaprosesdarinegarapengembangan khususnya diSektor ekonomi.Jadi bank syariah sebagai pemasok dana juga wajib menunjukitu nasabah untuktidak memanfaatkan sumber daya alam yang digunakan aktivitas produksi. Dengan demikian pembangunan Indonesia di bidang ekonomi bisa jadi dilakukan terus sampai generasi penerus (Jimly Asshiddiqie, 2010). 
Published July 2018

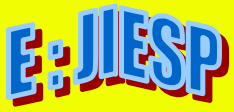

EKONOMIKAWAN : Jurnal Ilmu Ekonomi dan Studi Pembangunan

ISSN : 1693-7600 (Print), ISSN : 2598-0157 (Online), http://jurnal.umsu.ac.ld/index.php/ekawan

Kemudian disamping perbankan syariah juga menekankan prinsip ekologis. Dalam hal ini, konsep green economy akan dapat diimplementasikan. Padahal, konsep ini mengarahkan pembangunan ekonomi yang mendasari pengetahuan terhadap ekonomi ekologis yang diarahkan pada pondasi saling ketergantungan antara ekonomi dan ekosistem dan dampak negatif akibat ekonomi kegiatannya meliputi perubahan iklim dan pemanasan global (Makmun Syadullah, 2010).

Untuk mendukung green banking, bank syariah perlu menerapkan konsep perbankan dengan kontrak pembiayaan. Dimana mengutamakan aspek-aspek berkelanjutan, baik ekonomi, lingkungan, sosial dan budaya, dan sekaligus teknologi. Jadi, untuk menerapkannya bisa dilakukan dengan menerapkan komponen yang ada sehingga terbangun sinergisitas dan optimalisasi antara bank syariah, debitur, lingkungan, dan tujuan pemerintah. Komponen-komponen tersebut adalah:

1. Segmen Nasabah

Bank syariah adalah perusahaan yang mempunyai perhatian terhadap lingkungan, perusahaan yang kegiatan usahanya tidak mengalami kerusakan lingkungan, juga perusahaan yang memiliki sertifikat ramah lingkungan.

2. Proposisi Nilai

Dengan menyalurkan dana pembiayaan kepada perusahaan yang ramah, lingkungan, hal ini bahwa bank syariah membuktikan kepada masyarakat dan menyatakan bahwa bank syariah berpartisipasi dalam menerapkan demokrasi ekonomi yang diamanatkan oleh UUD 1945.

3. Jaringan

Jaringan yang digunakan oleh bank syariah menuju green banking adalah B2C (business to customer), hal ini berarti penerapan green banking dimulai dari sisi internal. Bank syariah dapat menerapkan program efisiensi, dengan menerapkan pengurangan dan daur ulang. Hal itu bisa dilakukan dengan mengoptimalkan inovasi dan kreativitas praktisi bank syariah dan menggunakan teknologi. Sementara secara eksternal, bank syariah mendidik pihak nasabah yang berkepentingan untuk menawarkan produk perbankan Islami yang ramah lingkungan (eco-Produk).

4. Hubungan kepada nasabah

Hubungan antara bank syariah dan nasabah dilakukan melalui pendekatan pribadi (personal touch) dan kekeluargaan. Jadi hubungan dan komunikasi keduanya menjadi bagus serta saling percaya. Namun demikian, bank syariah selalu melakukannya Sebuah sistem dan pengawasan kepada nasabah sehingga pembiayaan yang diberikan sebenarnya tersebut digunakan untuk bisnis yang ramah lingkungan.

5. Pendapatan atau bagi hasil

Bank syariah yang melakukan pembiayaan terhadap bisnis ramah lingkungan mempunyai hak untuk menerima saham sesuai dengan rasio yang disepakati. Ini bisa digunakan sebagai sosialisasi kepada masyarakat luas terhadap visi dari bank syariah sebagai pelaku utama dalam green banking. 
Published July 2018

EKONOMIKAWAN : Jurnal Ilmu Ekonomi dan Studi Pembangunan

ISSN : 1693-7600 (Print), ISSN : 2598-0157 (Online), http://jurnal.umsu.ac.Id/index.php/ekawan

6. Sumber Daya Manusia

Bank syariah membutuhkan sumber daya manusia yang memiliki pengetahuan tidak hanya di bidang perbankan syariah, namun juga pengetahuan tentang pelestarian lingkungan. Dengan demikian, perlu dilakukan sertifikasi lingkungan sebagai persyaratan praktisi bank syariah. Di indonesia, Tidak ada persyaratan untuk karyawannya yang membutuhkan Memiliki sertifikat terkait lingkungan, sehingga hal ini dapat dipertimbangkan kedepannya.

7. Aktivitas

Bank syariah untuk menerapkan kegiatan green banking di IndonesiaSesuai dengan prinsip syariah dan demokrasi ekonomi (Prinsip ekologi pembangunan). Misalnya dengan menyediakan pembiayaan lingkungan proyek ramah lingkungan, seperti industri kreatif yang menggunakan limbah industri dan bisnis model memiliki kebaikan lingkungan. Dan hal lain yang bisa kita lakukan adalah mengubah laporan keuangan nasabah dari kertas kepada elektronik.

8. Mitra

Mitra bank syariah adalah komunitas lingkungan yang memiliki kesadaran tinggi terhadap lingkungan, seperti Walhi (Wahana lingkungan hidup) Dan Tunas Hijau. Bank syariah bekerja sama dengan masyarakat, secara aktif melakukan sosialisasi bisnis ramah lingkungan sebagai pemberdayaan lingkungan dan pemberdayaan masyarakat. Selain bank syariah juga perlu untuk berkolaborasi dengan pemerintah untuk mendukung operasional perbankan. Jadi, kerja sama antar beberapa pihak bisa terwujud green banking dengan mudah.

9. Struktur Biaya

Biaya yang dibutuhkan perbankan syariah untuk mewujudkan green banking adalah biaya untuk sumber daya manusia sebagai pelaksana green banking. Biaya lainnya juga diperlukan untuk proses penyaringan produk agar sesuai dengan prinsip syariah. Dari penjelasan di atas, dapat disimpulkan bahwa partisipasi perbankan syariah diwujudkan dalam bentuk pembiayaan, baik untuk perorangan maupun perusahaan. Dengan demikian, sebagai upaya meningkatkan kualitas partisipasi perbankan syariahnya, hal itu dapat direalisasikan dengan partisipasi untuk bertanggung jawab dalam menjaga kualitas lingkungan sebagai konsekuensi dari ditjen pembangunan nasional. 
Published July 2018

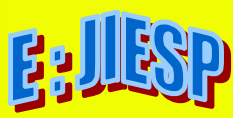

EKONOMIKAWAN : Jurnal Ilmu Ekonomi dan Studi Pembangunan

ISSN : 1693-7600 (Print), ISSN : 2598-0157 (Online), http://jurnal.umsu.ac.ld/index.php/ekawan

Berikut ini Sustainability Programs dari bank syariah sehingga terwujudnya suistainability development, yaitu sebagai berikut:

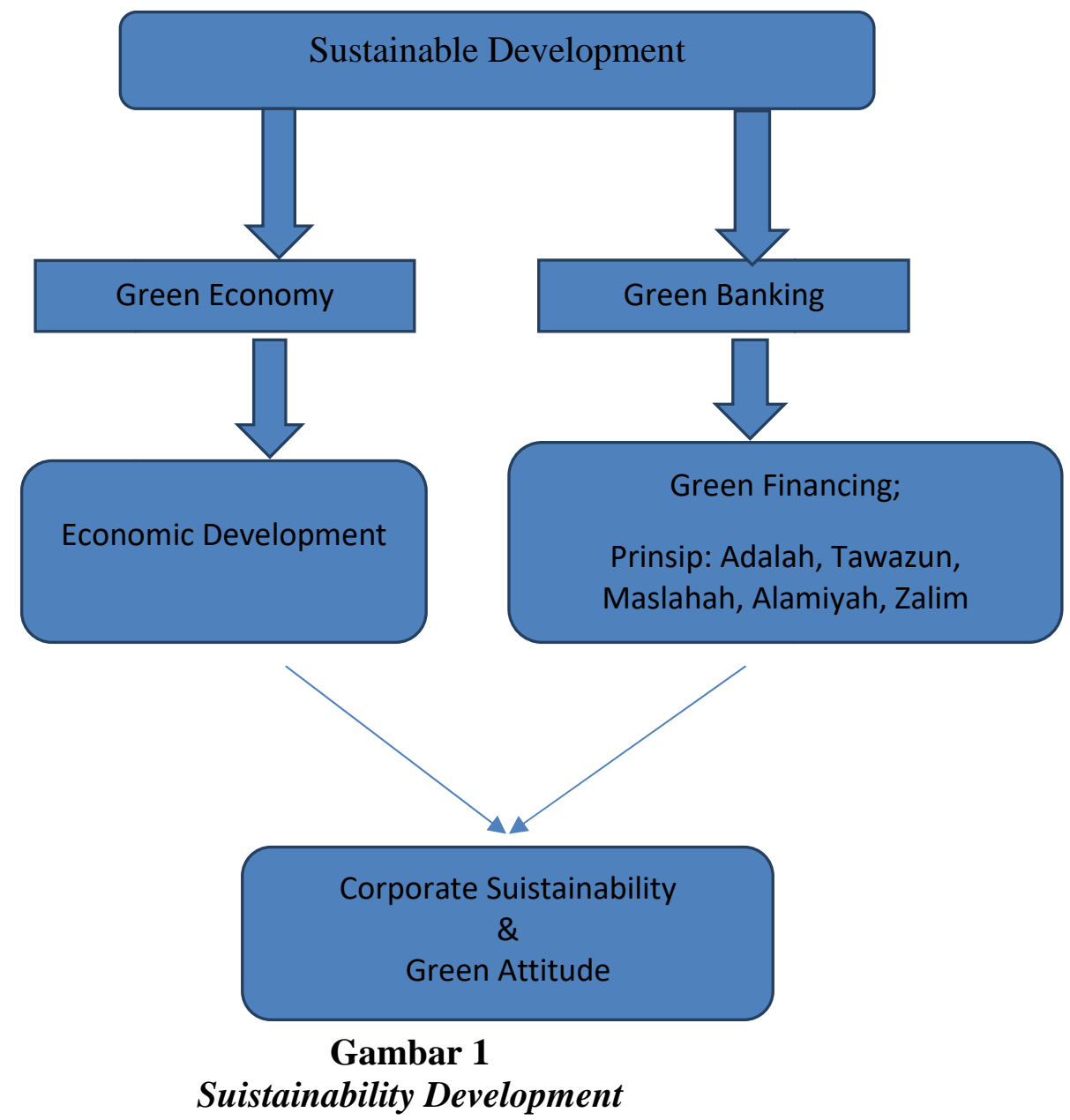

\section{SIMPULAN}

Green banking adalah salah satu upaya untuk merubah paradigma dalam pembangunan nasional dari greedy economy menjadi green economy, bank syariah diharapkan dapat bertanggung jawab melalui cara pembiayaannya, diharuskan untuk turut berperan dalam perusakan lingkungan. Artinya, bank harus mempertimbangkan bahwa kegiatan yang dijalankan oleh debiturnya memiliki dampak negatif terhadap lingkungan atau tidak, yaitu dengan melakukan penyaluran pembiayaan pada sektor atau industri ramah lingkungan seperti energi terbarukan (renewable energy), produk organik, industri kreatif yang memanfaatkan limbah, produk efisien (high end product), pengolah limbah, serta pertanian dan kehutanan, menerapkan prinsip sustainability dalam analisa kelayakan pembiayaan debitur secara bertahap sebagai bagian klausul pembiayaan serta dipercaya menjadi bank penyalur pembiayaan dari lembaga-lembaga dunia untuk proyek lingkungan.

Prinsip-prinsip syariah relevan dan tidak bertentangan dengan tujuan regulasi green economy, bahkan jauh dari sebelum adanya wacana green economy prinsip-prinsip syariah sebenarnya telah mengambil peran besar dalam pelestarian atau penjagaan lingkungan. 
Published July 2018

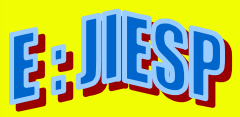

EKONOMIKAWAN : Jurnal Ilmu Ekonomi dan Studi Pembangunan

ISSN : 1693-7600 (Print), ISSN : 2598-0157 (Online), http://jurnal.umsu.ac.Id/index.php/ekawan

Tentunya, regulasi green economy ini disambut baik oleh perbankan syariah karena sesuai dengan prinsip-prinsipnya. Oleh karena itu, semestinya ini memberi kekuatan baru bagi perkembangan bank syariah dimana seharusnya bank syariah tersebut dapat menjadi pelopor dan acuan terdepan dalam pengaplikasian green economy dan green banking, misal dalam kebijakan pembiayaan dan prosedur operasional bank syariah, mekanisme screening pembiayaan dan investasi menetapkan negative list usaha haram seperti alkohol, persenjataan, perjudian, usaha berdampak kerusakan moralitas, juga kegiatan bisnis nyata yang berdampak mengancam sustainabilitas kelestarian lingkungan hidup. Oleh karenanya, prinsip syariah mengambil peran penting dan besar untuk mendukung gerakan pelestarian lingkungan.

\section{DAFTAR PUSTAKA}

Ajeng Radyati. UrgensiPengaturan Green Banking DalamKreditPerbankan di Indonesia. (Malang: Brawijaya University Press).

Broto Rauth Bhardwaj dan Aarushi Malhotra. 2013. Green Banking Strategies: Sustainability through Corporate Entrepreneurship. dalamJurnal Greener Journal of Business and Management Studies. Vol 3. Mei 2013.

Ikatan Bankir Indonesia.Memahami Bisnis Bank Syariah.(Gramedia Pustaka Utama: Jakarta, 2014).

Karim, A. Adiwarman.Bank Islam Analisis Fiqih dan Keuangan.(Raja Grafindo Persada: Jakarta, 2010).

Sjahdeni, Remi Sultan. Perbankan Syariah. (Kencana Prenada Media Group: Jakarta, 2014).

Soemitra, Andri. Bank dan Lembaga Keuangan Syariah.(Kencana Prenada Media Group: Medan, 2009).

Umam, Khaerul. Manajemen Perbankan Syariah. (Pustaka Setia: Bandung)

United Nations Environment Programme Finance Initiative. 2011. UNEP FI Guide to Banking \& Sustainability.

Daeng Naja, H.R., Hukum Kredit dan Bank Garansi, The Bankers Book.(Bandung : Citra Aditya Bakti, 2005).

Erwin, Muhammad, Hukum Lingkungan dalam Sistem Kebijaksanaan Pembangunan Lingkungan Hidup(Bandung : P.T. Refika Aditama, 2008).

Fandeli, Chafid, Analisis Mengenai Dampak Lingkungan Prinsip Dasar dan Penerapannya dalam Pembangunan. (Yogyakarta : Liberty Offset, 1995).

Fuady, Munir, Hukum Perkreditan Kontemporer.(Bandung : P.T. Citra Aditya Bakti, 1996).

Hamzah, Andi, Penegakan Hukum Lingkungan. (Jakarta : CV. Sapta Artha Jaya, 1997).

Hardjasoemantri, Koesnadi, Hukum Tata Lingkungan.(Yogyakarta : Gajah Mada

University Press, 1999).

Hermansyah, Hukum Perbankan Nasional Indonesia. (Jakarta : Kencana Prenada Media Group, 2005).

Lubis, M. Solly, Filsafat Ilmu dan Penelitian, (Bandung : CV. Mandar Maju, 1994).

Moleong, Lexy J., Metodologi Penelitian Kualitatif. (Bandung : Remaja Rosdakarya, 1993). 
Published July 2018

EKONOMIKAWAN : Jurnal Ilmu Ekonomi dan Studi Pembangunan

ISSN : 1693-7600 (Print), ISSN : 2598-0157 (Online), http://jurnal.umsu.ac.Id/index.php/ekawan

Rahman, Hasanuddin, Kebijakan Kredit Perbankan yang Berwawasan Lingkungan.

(Bandung : P.T. Citra Aditya Bakti, 2000).

Riyanto, Eggi Sudjana, Penegakan Hukum Lingkungan dalam Perspektif Etika Bisnis di Indonesia. (Jakarta : P.T. Gramedia Pustaka Utama, 1999).

Salim, Emil, Pembangunan Berwawasan Lingkungan. (Jakarta : LP3ES P.T. Media Surya Grafindo, 1988).

Siahaan, N.H.T., Hukum Lingkungan. (Jakarta : Pancuran Alam, 2009).

Silalahi, M. Daud, AMDAL Dalam Sistem Hukum Lingkungan di Indonesia. (Bandung: CV. Mandar Maju, 1995). 